\title{
Relational Contracting in Pakistan's Surgical Instrument Cluster: An Empirical Study
}

\author{
THERESA THOMPSON CHAUDHRY
}

\begin{abstract}
This paper tests an idea from relational contracting theory [Macauley (1963); North (1990); Greif (1994); Kranton (1996)] that informal relationships can substitute for formal contract enforcement through the judicial system, from the analysis of a new survey of the surgical instrument cluster in Sialkot, Pakistan. Inter-firm trust is thought to lead to reduced transaction costs (a passive benefit of a cluster). Considered here are exchanges of goods between clustered suppliers and their customers, who are either members of the cluster or firms that interact frequently with it. Inter-firm trust is measured as the amount of trade credit offered to customers. The results show that suppliers are more likely to offer trade credit when they believe in the effectiveness of formal contract enforcement and when they participate in business networks (proxied by inter-firm communication). There is also some evidence that customer lock-in helps to develop inter-firm trust since firms give more credit when relationships are of longer duration, and as locked-in customers are less able to find alternate suppliers.
\end{abstract}

\section{JEL classification: O12, L14}

Keywords: Microeconomic Analyses of Economic Development, Transactional Relationships, Contracts and Reputation, Networks.

\section{INTRODUCTION}

Industrial clusters have been viewed as important in developing countries because they make sizeable contributions to their economies in terms of employment, output, and exports. ${ }^{1}$ An industrial cluster consists of a group of firms that are specialised by sector, are located in close geographic proximity, and consist of mostly small and medium sized enterprises. $^{2}$ The benefits to firms from clustering are commonly referred to as active and passive collective efficiency. Passive collective efficiency refers to benefits accruing to a firm by virtue of being in a cluster, such as market access, access to a large pool of skilled labour, technological spillovers, flexible specialisation, and reduced transaction costs. Active collective efficiency, on the other hand, stems from purposeful cooperation between the firms of the cluster to undertake a large-scale project to upgrade production. ${ }^{3}$

Theresa Thompson Chaudhry <theresamariethompson@hotmail.com> is Associate Professor in the Department of Economics, Lahore School of Economics, Lahore.

Author's Note: I am thankful to anonymous referees of this journal for their comments on earlier versions of this paper. The usual disclaimer applies.

${ }^{1}$ Clusters produce a significant amount of output, with a great deal of this output bound for the export market. For example, India's Palar Valley clusters produce forty-five percent of the country's leather, where there are at least 600 tanneries in five clusters. In Tiruppur, India, there were at least 2000 clustered cotton knitwear firms in 1995, which produced about 70 percent of India's exports of this commodity [Banerjee and Munshi (2000)]. In Ludhiana, India, there were 10,000 firms and 200,000 workers producing Rs 241 billion (almost $\$ 10$ billion in U.S. 1991 dollars) of woolen knitwear in 1991 [Tewari (1999)]. In Agra, India, 5000 clustered firms were producing 300,000 pairs of shoes per day in 1991-92 [Knorringa (1999)].

${ }^{2}$ For example, clusters in Sinos Valley (Brazil), Agra (India), and Guadalajara and Leon (Mexico) all produce footwear. Other clusters that have been studied specialise in the production of textiles, leather goods, and surgical instruments.

${ }^{3}$ Schmitz and Nadvi (1999), p. 1504. 
This paper empirically examines one aspect of passive collective efficiency-the transaction costs the clustered firms encounter in their dealings with customers and suppliers - using the responses from a survey of the surgical instrument cluster in Sialkot, Pakistan. Specifically, we test the hypothesis that relational contracting affects the amount of trust between firms, where trust is measured by the receipt of trade credit by customers from their suppliers. The firms receiving trade credit are either members of the cluster or firms that interact frequently with it.

The importance of institutions, especially contract enforcement, has been well established in both theoretical and empirical economic literature. The absence of strong institutions has been recognised as a major constraint to economic growth in developing countries. As Douglass North argues in his seminal work on institutions:

...the inability of societies to develop effective, low-cost enforcement of contracts is the most important source of both historical stagnation and contemporary underdevelopment in the Third World. ${ }^{4}$

Research has shown that in the absence of an effective legal system or formal system of contract enforcement, individuals and firms must rely on informal means to enforce agreements. In many cases, bilateral relationships or third-party social pressure may either substitute for, or complement, a legal system in the enforcement of contracts. This type of informal enforcement of contracts is referred to as relational contracting. Relational contracts are "informal agreements sustained by the value of future relationships". 5 The methods of informal enforcement have been laid out in the New Institutional Economics literature and consist of the agents' ability to sanction individuals who have reneged on their agreements without relying on the legal system. ${ }^{6}$

North (1990) presented three major methods that can be used to informally enforce agreements. One method is for an agent to deal only with those who are known to them and can be trusted, so that trading partners are most likely to be friends and family members. Another approach is to develop self-enforcing agreements by dealing with the same agent repeatedly over an extended period of time, using the threat of breaking off the profitable trading relationship as a means to prevent the other party from cheating. ${ }^{7}$ Finally, informal enforcement can also be carried out through community enforcement. In this situation, when an agent reneges on an agreement, all members of the community sanction this individual by refusing to trade with that agent. To be effective, community enforcement has two major requirements, (i) that knowledge about cheaters is diffused through the community, and (ii) that other members of the community are willing to refuse to trade with a known cheater. Community enforcement is therefore often limited to a specific geographic area and/or to agents of a common cultural or social background.

${ }^{4} \operatorname{North}(1990)$, p. 54

${ }^{5}$ See Baker, Gibbons, and Murphy (2002).

${ }^{6}$ See Macauley (1963), North (1990), Greif (1994), Kranton (1996). Kranton (1996) studied a theoretical model of reciprocal exchange, where the value of long-term relationships can support barter between two trading partners, and found that reciprocal exchange relationships can dominate in an economy even when they are a less efficient mode of exchange. Greif (1994) explored the path dependence of contract enforcement institutions by examining the difference between the eleventh-century trading practices of Genoese and Maghribi traders and distinguished between the individualist and collectivist enforcement systems that were the precursors to modernday institutions. The collectivist system, characteristic of contract enforcement institutions in developing countries today, relied strongly on community enforcement mechanisms and social sanctions.

${ }^{7}$ Self-enforcing agreements may be characterised by high search costs and/or high transport costs to buy from alternate suppliers. A firm must be able to identify their trading partners (i.e., know who they are trading with at the time of the trade) and be able to determine if a trading partner has cheated. 
In practice, informal enforcement is carried out through a combination of the three methods described above: trust, repeated interaction, and community enforcement. The combination used in practice depends on the environment in which the parties are contracting. The particular characteristics of clusters may make some contract enforcement mechanisms more effective than others. For instance, since all firms produce similar goods, the threat of an individual intermediate input supplier breaking off a trading relationship with a manufacturer (customer) is unlikely to prevent cheating unless there is community enforcement due the multiplicity of similar suppliers. Therefore, we hypothesise that community enforcement is likely to be a stronger force than sanction by an individual firm in a cluster.

Is this paper, we aim to identify the factors that influence the amount of trust (associated with informal contract enforcement or relational contracting), first between the clustered firms and their customers, and second, between clustered manufacturers and their intermediate input suppliers.

Our results show that firms are more likely to offer trade credit to their customers, (i.e., inter-firm trust is greater) when they believe in the effectiveness of formal contract enforcement through the court system. There is also some evidence of customer lock-in as a tool for contract enforcement since suppliers are more likely to give credit and allow customers to pay a larger portion of their bill with delay when relationships are of longer duration. The hypothesised cause is that locked-in customers are less able to find alternate suppliers. Participation in business networks (that can be used to gather information about reliability and/or for social sanction) is also an effective tool in that suppliers that obtain information about customers through business networks are more likely to offer trade credit and allow customers to pay a larger portion of their bill with delay. Additionally, customers are less likely to receive credit when they are visited by suppliers before the first sale. If a customer receives a visit from the supplier before the first sale, this may indicate that it is a previously unknown trading partner, and therefore not fully trusted. On the other hand, customers that visit their suppliers weekly are more likely to receive trade credit. These visits may assist the suppliers in gathering information about the reliability of the firms as well as to monitor informal contracts.

This paper is presented in six sections. In Section 1, the introduction, we have defined and summarised the study. Section 2 discusses some of the empirical literature related to clusters. In Section 3, the surgical instrument cluster of Sialkot (Pakistan) is introduced, along with the survey methodology and the estimation strategy for the relational contracting regressions in Section 4. In Section 5 we discuss the results of the relational contracting regressions for trade credit offered to customers. Our conclusions are presented in Section 5.

\section{EMPIRICAL LITERATURE}

Two earlier papers, by McMillan and Woodruff (1999) and Johnson, McMillan, and Woodruff (2002), used an innovative survey instrument to test the hypothesis of relational contracting in two environments where the judicial system is not fully developed, first in Vietnam and then in Eastern Europe. As discussed above, informal relationships can substitute for third party enforcement through relational contracting. The measure of trust used as the dependent regression variable was the amount of trade credit that a supplier offered to its customers. In Vietnam, they found that the amount of trade credit given to a 
customer is positively related to the difficulty of finding a new supplier, a longer duration of the trading relationship, and the identification of customers through business networks. Johnson, McMillan, and Woodruff (2002) conducted a similar survey in five Eastern European countries: Poland, Slovakia, Romania, Russia and Ukraine. In addition to relational contracting variables, they included the role of the judiciary in this second study, because the court systems in Eastern Europe are considered to be stronger than those in developing countries such as Vietnam. Their study found that greater confidence in the court system made firms more likely to offer trade credit and to try new lower cost suppliers. The effect of courts was greatest at the beginning of a trading relationship.

We use a methodology similar to McMillan and Woodruff (1999) and Johnson, McMillan, and Woodruff (2002) and apply it to data from an industrial cluster in Sialkot Pakistan. Our research makes a unique contribution to the literature since this aspect of relational contracting has not yet been studied empirically in the context of a cluster.

In a related study, Fisman and Raturi (2000) also used trade credit data to study in terfirm trust, though they use a different methodology. Studying trade credit data from Africa, they showed how competition could encourage long-term cooperative relationships when trading partners must make non-contractible investments at the beginning of the relationship. ${ }^{8}$

While most of the literature on the topic of industrial clusters in developing countries has consisted of case studies, there are a few papers that have empirically analysed the effects of social network-based relationships on economic activity in clusters. Woodruff's (1998) case study of a shoe-producing cluster in Mexico demonstrated the importance of community sanctions for contract enforcement in a cluster. ${ }^{9}$ Ilias (2001) and Banerjee and Munshi (2000) used empirical analysis to verify the existence and sometimes distortionary effects of these types of relationships in clusters. ${ }^{10}$ This paper extends the empirical literature on clusters to include results on relational contracting to enforce contracts.

\section{THE SURGICAL INSTRUMENT CLUSTER IN SIALKOT: DESCRIPTION OF THE CLUSTER AND SURVEY}

\section{The Cluster}

There is a cluster of firms consisting of approximately 220 producers and 1500 subcontracting firms in Sialkot, a city in the Punjab province of Pakistan (see Table 1), which produces surgical instruments mainly for foreign markets including the United States and Western Europe, with 36 percent and 39 percent of instruments being exported to these

${ }^{8}$ Fisman and Raturi (2000) use fixed-effects regression analysis to show that greater competition is associated with higher provision of trade credit. Suppliers use trade credit in order to attract customers. Once a customer and supplier have invested in building trust, then the customer is "locked-in" to the relationship.

${ }^{9}$ Woodruff (1998) presents a case study examining the impact of trade liberalisation on the Mexican footwear industry, based on a qualitative analysis of surveys conducted in the Guadalajara and Leon clusters. He finds that trade liberalisation weakened the ability of cluster manufacturers to use informal contract enforcement mechanisms (reputation) with respect to retailers.

${ }^{10}$ Ilias (2001) focuses on the role of family labour in the Sialkot surgical instrument cluster and the distortionary effects of the decision to use family versus non-family labour. He concludes that there existed a labour market distortion such that family managers are preferred to non-family and therefore firm output is correlated with family size. Banerjee and Munshi (2000) present a theoretical model and empirical testing of social network-based lending, comparing the investment and earnings profiles of migrants and established producers (a caste called the Gounders) in the Tiruppur knitwear cluster in India. They find that the established producers, with access to cheaper informal credit through a social lending network, have lower output growth but invest more at all levels of experience as compared to the migrants. 
destinations respectively. ${ }^{11}$ For the most part, the U.S. imports Sialkot's disposable (singleuse) instruments, and Europe imports re-useable instruments. ${ }^{12}$ In addition to surgical instruments, the cluster also produces a small amount of veterinary and manicure/pedicure instruments. This cluster's output is significant, as verified by the $\$ 124$ million worth of goods exported in 2000-2001. ${ }^{13}$ The firms of the cluster manufacture approximately 10,000 different types of disposable and re-useable surgical instruments. ${ }^{14}$

In the cluster, production of the surgical instruments takes place in stages, including input production, manufacturing, and complementary services. The large vendor segment consists of small firms that specialise in one or more stages of the production process. There is a negative correlation between firm size and the percentage of sub-contracted manufacturing processes, and the largest firms carry out 80-90 percent of production processes in-house. ${ }^{15}$ Except for the largest manufacturers, production of a final good is not generally carried out in a single, vertically integrated firm.

The cluster also has local business associations, including the Metal Industries Development Centre, the Sialkot Dry Port Trust, the Sialkot Chamber of Commerce and Industry (SCCI) and the Surgical Instrument Manufacturer's Association (SIMA).

Table 1

Surgical Instrument Firms in Pakistan

\begin{tabular}{lllll}
\hline $\begin{array}{l}\text { Size of } \\
\text { Firm }\end{array}$ & $\begin{array}{l}\text { Number of } \\
\text { Firms }\end{array}$ & $\begin{array}{l}\text { Number of } \\
\text { Employees }\end{array}$ & $\begin{array}{l}\text { Revenues } \\
\text { (Pakistan Rupees) }\end{array}$ & $\begin{array}{l}\text { Capital } \\
\text { (Pakistan Rupees) }\end{array}$ \\
\hline Large & 30 & $250-400$ & Rs 60-100 million & Rs 50-100 million \\
Medium & 50 & $100-250$ & Rs 10-60 million & Rs 10-25 million \\
Small & 150 & $30-50$ & Rs 1-10 million & Rs 1-5 million \\
Vendors & 2000 & $5-20$ & Rs 1-1.5 million & Rs 50,000-1 million \\
Traders & $800-1000$ & na & na & na \\
\hline
\end{tabular}

Source: Board of Investment, Government of Pakistan.

\section{Description of the Survey Instrument}

For purposes of this study, we designed and commissioned a survey of the surgical instrument cluster in Sialkot, based in large part on the survey questionnaire developed by McMillan and Woodruff (1999) for Vietnam and Johnson, McMillan, and Woodruff (2002) for their study in Eastern Europe and Russia. The faculty at the Lahore School of Economics in Lahore, Pakistan conducted the survey. A breakdown of the entire survey sample (before data cleaning) is provided in Table 2.

Table 2

Survey Sample (All Firms Surveyed)

\begin{tabular}{lcccc}
\hline & $\begin{array}{c}\text { Number of } \\
\text { Firms }\end{array}$ & \% of Sample & $\begin{array}{c}\text { Average } \\
\text { Employment } \\
\text { (No. of Workers) }\end{array}$ & $\begin{array}{c}\text { Average Age of } \\
\text { Firms (Years) }\end{array}$ \\
\hline Exporters & 76 & $62 \%$ & 91.8 & 19.9 \\
Vendors & 47 & $38 \%$ & 15.4 & 11.7 \\
All Firms & 123 & & 61.9 & 16.7 \\
\hline
\end{tabular}

\footnotetext{
${ }^{11} \operatorname{SMEDA}(2001), \mathrm{p} .16$.

${ }^{12} \operatorname{SMEDA}(2001), \mathrm{p} .17$.

${ }^{13} \operatorname{SMEDA}(2001)$, p. 13.

${ }^{14}$ SMEDA(2001), p. 21.

${ }^{15} \operatorname{SMEDA}(2001)$, p. 39.
} 
When the interviewer went to the cluster to begin the survey, she found that only about 180 of the 220 exporting firms that were listed by SIMA (the local business association) were actually in operation at that time.$^{16}$ Of these, 76 firms at least partially answered the survey, leading to a response rate of 43 percent. The interviewer then met with 47 vendor firms in the villages surrounding Sialkot, where the cottage industry is located.

\section{THE ANALYSIS OF RELATIONAL CONTRACTING: TRADE CREDIT AS A MEASURE OF INTER-FIRM TRUST}

\section{Dependent Variable: Trade Credit as a Measure of Inter-firm Trust}

This study examines elements of relational contracting in the context of Sialkot's surgical instrument cluster in a country where the institutional environment is characterised by weak third party enforcement.

The measure of trust used as the dependent regression variable in the relational contracting regressions is trade credit offered to customers. More specifically, we asked each surveyed firm about the amount of trade credit they offered to two customers (their oldest and newest customers) and received from two suppliers (their oldest and newest suppliers). ${ }^{17}$ This approach helped to increase the number of observations and heterogeneity in the characteristics of the surveyed firms' customers and suppliers. ${ }^{18}$

In addition to questions about trade credit and the length of relationships with the oldest and newest customers and suppliers, firms were asked several other questions about the nature of their trading relationships and contract enforcement, including questions about their belief in the effectiveness of local courts, how often they visit customers and suppliers, how they were introduced to their customers and suppliers, how difficult it would be to find alternate customers or suppliers, and whether social sanctions existed for reneging on contracts.

Since the work of McMillan and Woodruff (1999) and Johnson, McMillan, and Woodruff (2002) was not related to clusters, the particular characteristics of clusters may yield somewhat different results from those obtained in their studies of Vietnam and Eastern Europe. For instance, one of McMillan and Woodruff's results in Vietnam was that firms were more likely to trust customers (and therefore offer trade credit) the more difficult it was for that customer to find an alternate supplier. In a cluster, manufacturing firms (as customers) have numerous alternate suppliers of similar (although perhaps not identical) intermediate inputs. Therefore, the absence of alternate suppliers is less likely to be a deterrent to reneging on contracts unless intermediate inputs are highly specialised. Because of this, we hypothesise that information sharing and network effects are more likely to be significant determinants of trust and contract enforcement in a cluster environment.

\footnotetext{
${ }^{16}$ The survey was carried out in Spring 2002. See Appendix 3 for more details.

${ }^{17}$ There may be a variety of reasons for offering trade credit to a customer, so that the trade credit may function as a source of informal credit, a way of attracting (and keeping) customers or as a means of quality assurance on the part of the supplier. The terms of the trade credit may differ (the cash vs. credit price of goods, and the time until full payment) depending on the reason the credit is given. While these are important issues for firms' access to finance and other aspects inter-firm relationships, the focus in this paper is on "trust". Regardless of the reason for the trade credit, it will only be given when the supplier trusts that the customer will repay.

${ }^{18} \mathrm{As}$ can be seen in Table A12, both exporter and vendors firms give and receive trade credit, but not in the same proportions. Exporters in the sample give trade credit in greater proportions than they receive, but the reverse is the case among the vendors. (Out of 53 exporters, 37 give trade credit, and 27 receive trade credit. Out of 42 vendors, 30 give trade credit and 39 receive trade credit.)
} 


\section{Regression Equations for Estimation}

We estimate a model of the probability that a firm offers positive trade credit to its customer (where trade credit is a proxy for inter-firm trust), applying the probit estimation method and using the following equation:

$$
P_{i}=\alpha+\beta R_{i}+\gamma B_{i}+\delta S_{i}+\phi Z_{i}+\varepsilon_{i} \quad \cdots \quad \ldots \quad \cdots \quad \ldots \quad \cdots
$$

where $P_{i}$ is the probability of offering trade credit to its customer, $R_{i}$ is a vector representing factors that characterise the relationship between the firm and its customer, $B_{i}$ is a vector of firm characteristics, $S_{i}$ is a vector of customer characteristics, and $Z_{i}$ represents firm-level controls.

We also estimate a model of the probability that a firm receives positive trade credit from its supplier, applying the probit estimation method, using the following equation.

Similarly, the regression equation for the amount of trade credit offered to customers (where trade credit is a proxy for inter-firm trust) took the following form:

$$
T C_{i}^{*}=\alpha+\beta R_{i}+\gamma B_{i}+\delta S_{i}+\phi Z_{i}+\varepsilon_{i} \quad \cdots \quad \ldots \quad \ldots \quad \ldots \quad \cdots
$$

where $T C_{i}^{*}$ is the desired level of trade credit that a firm wishes to give its customer (trade credit is defined as the percentage of the bill paid with delay).

Since we can only measure observed trade credit that is restricted to values between 0 percent and 100 percent, ${ }^{19}$ a tobit model is estimated such that the censored dependent variable takes the following form:

$T C_{i}$ is the observed level of trade credit, where:

$$
\begin{aligned}
& T C_{i}=T C_{i}^{*} \text { for } 0<T C_{i}^{*}<1 \\
& T C_{i}=0 \text { for } T C_{i}^{*} 0 \\
& T C_{i}=1 \text { for } T C_{i}^{*} 1
\end{aligned}
$$

\section{Explanatory Variables in the Estimations}

The relational contracting variables fall into four categories. First, we consider the lock-in of the customer or the ability of the customer to find an alternate supplier, which is measured by asking how long it would take a customer to find an alternate source if the supplier failed to deliver the inputs. The hypothesis is that "locked-in" customers will receive higher trade credit because it is more difficult for them to find alternate suppliers if they fail to pay. Second, information gathering by firms about their customers may increase trade credit, which is measured by the duration of the trading relationship (and duration-squared to measure non-linear effects) and visits between suppliers and customers. Duration may also be interpreted as customer lock-in; longer duration relationships may signify greater customer lock-in for a number of reasons including, but not limited to the following: (i) inputs may become more specialised or more tailored to the customer's specifications over time, (ii) production of specialised

${ }^{19}$ In the sample of trade credit offered to customers, 59 observations are censored at percent, 24 observations are censored at 100 percent, and 49 observations are not censored. 
inputs may require a fixed investment by the supplier which is recouped over time, or (iii) the customer has better information about a supplier that it has been working with for an extended period (i.e. the customer has better information about the reliability and expected quality of a supplier) and becomes reluctant to change suppliers. Third, we have several variables to capture the positive effects of networks in increasing trade credit by building trust between a firm and its customers. These networks may assist in gathering information about a customer at the beginning of a trading relationship, such as if the firm was introduced to the customer or received information about the customer's trustworthiness through a business or social network. ${ }^{20}$ Networks may also increase trade credit by helping firms to sanction delinquent customers and with continuous information gathering, which is measured by the frequency with which the firm speaks to other suppliers. Lastly, we consider the effect of the firms'belief in formal and informal contract enforcement institutions on the decision to offer trade credit, as a way to measure the ability of firms to sanction delinquent customers. Formal contract enforcement is measured by a dummy variable that the respondent believes that courts can enforce contracts. Informal enforcement may be measured by dummy variables about the respondent's belief in the strength of social sanctions, such as the belief that other firms would find out about a cheating customer, or that a trade dispute would lead suppliers to demand higher advanced payments for inputs (in other words, less trade credit). We also control for other firm level characteristics, including firm size, age, and whether the firm is an exporter.

We recognise that a potential problem arises if the duration of trading relationships is correlated with trade credit incidence, in which case sample selection is based in part on the error term. Specifically, the sampling of the oldest customers and oldest suppliers would create a sample selection bias. There is in fact a noticeable difference between the average duration of the relationship with the oldest and newest customer and between the average duration of the relationship with the oldest and newest supplier (see Table 3). However, we believe that the sample selection method will not cause substantial bias in the estimates. There is considerable variation in the duration of trading relationships within-group. Since there is considerable variation in the ages of firms in the cluster (from less than one year to more than forty years old), there is also substantial variation in the duration of the relationships (see Table 3). Among the oldest customers, the average duration of the relationship is 10.5 years, with a standard deviation of 7 years. Among the oldest suppliers, the average relationship is almost 12 years, with a standard deviation of more than 8 years.

Summary statistics on the Sialkot sample in Table 4a show that the belief in the effectiveness of the court system is low, at an average of about 21 percent for all firms in the sample. In contrast, the average was about 74 percent for the Eastern European firms interviewed by Johnson, McMillan, and Woodruff (2002). However, the belief in courts in Pakistan is relatively higher than in Vietnam, where only 9 percent of firms answered this question affirmatively.

\footnotetext{
${ }^{20}$ “Information through a business contact" was constructed from the responses to a question in the survey asking about where information was gathered about the customer at the start of the relationship, where a value of "1" was assigned to the following responses: other businesspeople who make products similar to the firm, other suppliers, or credit bureau/business association (SIMA).
} 
Table 3

Variation in Ages and Duration of Relationships in Sample ${ }^{21}$

\begin{tabular}{lcccc}
\hline & Old Customers & New Customers & Old Suppliers & New Suppliers \\
\hline Age of Firm Surveyed & & & & \\
$\quad$ Mean & 15.2 & 16.3 & 16.5 & 17.8 \\
Std. Dev. & 10.4 & 11.1 & 11.3 & 11.8 \\
$\quad$ Median & 13.0 & 13.5 & 13.0 & \\
Duration of & & & & \\
$\quad$ Relationship & & & 11.9 & 2.8 \\
Mean & 10.5 & 2.7 & 8.4 & 3.2 \\
Std. Dev. & 7.0 & 2.6 & 10.0 & 2.0 \\
$\quad$ Median & 10.0 & 2.0 & 61 & 52 \\
Sample Size & 68 & 64 & & \\
\hline
\end{tabular}

\section{RELATIONAL CONTRACTING RESULTS I}

\section{Trade Credit Offered to Customers}

We consider the impact of the relational contracting variables on the probability that a clustered firm offers trade credit to its customers and the amount of trade credit offered. Once the dataset was cleaned and balanced, 132 observations remained for the customer credit regressions representing 72 unique firms in the survey. For 60 firms, there are two observations per firm (representing both their oldest and newest customers) and for 12 firms, there is only adequate information on one of their customers, either the oldest or the newest. ${ }^{22}$ The breakdown of firm size (by employment) in our sample was as follows: 14 firms with up to 10 employees, 33 firms with 11-25 employees, 12 firms with 26-50 employees, 4 firms with 51-100 employees, 7 firms with 101-250 employees, and 2 firms with more than 250 employees.

\section{Discussion of the Summary Statistics}

Summary statistics on the variables used in the customer credit regressions are presented in Table 4a.

The most marked and obvious difference between vendors and exporters is the size of the firm in terms of employment (average of 15.5 versus 85 workers, respectively). Employment among the vendors ranges from 6 to 36 employees, and for exporters from 6 to 585 employees. Despite this wide range, only 13 of the 71 exporters in the sample had more than 50 employees. The exporters are on average more mature firms as well, with an average age of almost 19 years, as compared to the vendors that are approximately 12 years old on average. Other important dimensions on which exporters and vendors differ is the reliance on social and business networks for introductions, with vendors relying more on the former, and exporters on the later.

Exporters and vendors appear to be equally locked-in to their relationships with suppliers, which can be seen by looking at the length of time it would take the firm to find

\footnotetext{
${ }^{21}$ Note that the mean, standard deviation and median of the age variable are referring to the age of the firm that was surveyed, not the age of the customer or supplier. The summary statistics for age of the firm surveyed varies slightly between old and new customers because the two samples are slightly different; there are 8 firms for which there was only sufficient data for their oldest customers, and 4 firms for which there was only sufficient data for their newest customers.

${ }^{22}$ When comparing firms with partial data to those with full data (variable by variable), the t-stats for differences in the means of the included vs. excluded observations were in most cases insignificant. However, in the interest of space, these results are not reported.
} 
alternate customers for their output. On the other hand, it appears that the exporters believe their customers are relatively more locked-in than those of the vendors; for the vendors they believe that 95 percent of their customers would be able to find an alternate source of supply within a month, whereas the exporters believe that for nearly half of their customers it would take more than a month to find an alternate supplier.

Both exporters and vendors give substantial amounts of trade credit to large shares of customers. Considering the firms' oldest and newest customers, half of the exporters' and nearly two-thirds of the vendors' customers received trade credit, and the average trade credit given was 40 percent and 31 percent of the value of the goods respectively. But as we can see in Table $4 \mathrm{~b}$, the amount of trade credit awarded to customers is clustered at 0 percent, 50 percent, and 100 percent.

Table 4a

\begin{tabular}{|c|c|c|c|c|c|c|}
\hline & $\begin{array}{l}\text { Average } \\
\text { for } \\
\text { Sample } \\
\end{array}$ & Vendors & Exporters & $\begin{array}{l}\text { \# Obs. } \\
\text { Vendors }\end{array}$ & $\begin{array}{l}\text { \# Obs. } \\
\text { Exporters }\end{array}$ & $\begin{array}{r}\text { Total } \\
\text { Number of } \\
\text { Observations } \\
\end{array}$ \\
\hline Firm Age & 15.73 & 12.16 & 18.80 & 61 & 71 & 132 \\
\hline Employment & 52.51 & 15.46 & 84.35 & 61 & 71 & 132 \\
\hline Duration of Relationship (Years) & 6.74 & 6.42 & 7.01 & 61 & 71 & 132 \\
\hline Percentage Sales to this Customer & 36.54 & 39.49 & 33.26 & 61 & 55 & 116 \\
\hline $\begin{array}{l}\text { Network Introduction (Business or } \\
\text { Social) }(0,1)\end{array}$ & 0.55 & 0.68 & 0.44 & 53 & 61 & 114 \\
\hline Business Network Introduction $(0,1)$ & 0.19 & 0.04 & 0.31 & 53 & 64 & 117 \\
\hline $\begin{array}{l}\text { Business Network for Information on } \\
\text { Customer }(0,1)\end{array}$ & 0.44 & 0.70 & 0.21 & 61 & 71 & 132 \\
\hline Social Network for Information $(0,1)$ & 0.13 & 0.08 & 0.17 & 61 & 71 & 132 \\
\hline Trade Credit given $(0,1)$ & 0.55 & 0.62 & 0.49 & 61 & 71 & 132 \\
\hline Time before Credit given (Years ) & 1.04 & 0.56 & 1.79 & 38 & 24 & 62 \\
\hline Trade Credit given $(\%)$ & 35.91 & 31.15 & 40.00 & 61 & 71 & 132 \\
\hline $\begin{array}{l}\text { Less than a Week (for Firm to Find } \\
\text { Alternate Customer for Output ) }(0,1)\end{array}$ & 0.15 & 0.15 & 0.15 & 61 & 67 & 128 \\
\hline $\begin{array}{l}\text { More than a Month or Impossible (to } \\
\text { Find Alternate Customer ) }(0,1)\end{array}$ & 0.71 & 0.75 & 0.67 & 61 & 67 & 128 \\
\hline $\begin{array}{l}\text { Less than a Week (for my Customer to } \\
\text { Find new Supply) }(0,1)\end{array}$ & 0.30 & 0.21 & 0.38 & 61 & 71 & 132 \\
\hline $\begin{array}{l}\text { More than a Week, Less than a Month } \\
\text { (for my Customer to Find new Supply) } \\
(0,1)\end{array}$ & 0.43 & 0.74 & 0.17 & 61 & 71 & 132 \\
\hline $\begin{array}{l}\text { More than a Month or Impossible (for } \\
\text { my Customer to Find new Supply) }(0,1)\end{array}$ & 0.26 & 0.03 & 0.45 & 61 & 71 & 132 \\
\hline $\begin{array}{l}\text { Talk to other Producers at Least Weekly } \\
(0,1)\end{array}$ & 0.63 & 0.77 & 0.54 & 33 & 39 & 72 \\
\hline $\begin{array}{l}\text { Talk to other Producers at Least Monthly } \\
(0,1)\end{array}$ & 0.76 & 0.84 & 0.75 & 33 & 39 & 72 \\
\hline $\begin{array}{l}\text { Has (any) Customer ever Failed to } \\
\text { Deliver? }(0,1)\end{array}$ & 0.23 & 0.18 & 0.27 & 33 & 39 & 72 \\
\hline $\begin{array}{l}\text { Other Customers would Find Out if I } \\
\text { have a Dispute with my Customer }(0,1)\end{array}$ & 0.45 & 0.54 & 0.38 & 33 & 39 & 72 \\
\hline $\begin{array}{l}\text { Businesses would Refuse to Deal with a } \\
\text { Customer Unfair to me }(0,1)\end{array}$ & 0.42 & 0.34 & 0.49 & 33 & 39 & 72 \\
\hline $\begin{array}{l}\text { Local Gov't Useful for Resolving } \\
\text { Disputes with Customers }(0,1)\end{array}$ & 0.14 & 0.13 & 0.15 & 33 & 39 & 72 \\
\hline $\begin{array}{l}\text { I would Find out about a Dispute } \\
\text { between my Customer and another } \\
\text { Supplier }(0,1)\end{array}$ & 0.66 & 0.75 & 0.59 & 32 & 39 & 71 \\
\hline $\begin{array}{l}\text { If my Customer was Unfair with me, } \\
\text { Others would Find Out }(0,1)\end{array}$ & 0.45 & 0.40 & 0.49 & 31 & 37 & 68 \\
\hline $\begin{array}{l}\text { Courts help Resolve Disputes with } \\
\text { Customers }(0,1)\end{array}$ & 0.20 & 0.26 & 0.15 & 33 & 39 & 72 \\
\hline $\begin{array}{l}\text { SIMA (Trade Assoc) Good Source of info } \\
\text { about Customers }(0,1)\end{array}$ & 0.23 & 0.21 & 0.24 & 30 & 39 & 69 \\
\hline $\begin{array}{l}\text { SIMA helps to Resolved Disputes with } \\
\text { Customers }(0,1)\end{array}$ & 0.22 & 0.28 & 0.17 & 32 & 39 & 71 \\
\hline $\begin{array}{l}\text { Average Share of Bill Paid w/Delay to } \\
\text { Oldest and Newest Suppliers }\end{array}$ & 0.42 & 0.51 & 0.33 & 33 & 39 & 72 \\
\hline
\end{tabular}

Note: Dummy variables are indicated by $(0,1)$ next to their names. 
Table $4 \mathrm{~b}$

Distribution of Trade Credit percent across Customers

\begin{tabular}{ccc}
\hline Trade Credit Amount & $\begin{array}{c}\text { Number of Customers } \\
\text { Receiving }\end{array}$ & $\begin{array}{c}\% \text { of Customers } \\
\text { Receiving }\end{array}$ \\
\hline $0 \%$ & 58 & $43.9 \%$ \\
$10-24 \%$ & 2 & $1.5 \%$ \\
$25-49 \%$ & 9 & $6.8 \%$ \\
$50 \%$ & 34 & $25.8 \%$ \\
$51-74 \%$ & 1 & $0.8 \%$ \\
$75-99 \%$ & 4 & $3.0 \%$ \\
$100 \%$ & 24 & $18.2 \%$ \\
Total & 132 & $100.0 \%$ \\
\hline
\end{tabular}

Many firms simultaneously give and receive trade credit. Around half of vendors were simultaneously giving trade credit to both customers and receiving trade credit from both suppliers; however, this was only the case for about 20 percent of exporters (see Table A5). Two-thirds of exporters and nearly three-quarters of vendors gave trade credit to at least one of the two customers included in the survey. Nearly half of the exporters did not receive trade credit from either supplier, whereas this was only the case for less than 10 percent of vendors.

On other dimensions, particularly average duration of relationship (around 6.5 years) and share of sales going to a particular customer (near 40 percent), are about the same between the exporters and vendors. Although for each of these variables, there was substantial variation for both types of firms. For vendors, the share of sales going to a particular customer ranged from 4 percent to 100 percent, and for exporters the range was 1 percent to 98 percent. In terms of the share of sales going to a particular customer, for more than a third of vendors and nearly half of exporters, the particular customer accounted for 20 percent or less of total sales. For about another one-third of each type of firm, the particular customer accounted for 21-50 percent of sales.

Exporters and vendors both have substantial belief in informal contract enforcement mechanisms, ranging from 34 to 75 percent. On some dimensions, vendors display greater trust than exporters, while on others it is reversed. Belief in the effectiveness of more formal dispute resolution institutions (SIMA, local government, and the courts) is significantly lower, at between 13 and 28 percent. Vendors appear to have somewhat more confidence than exporters in courts and SIMA (the trade association) for their dealings with customers. The most likely explanation for this (despite the vendors' small size and, therefore, clout) is that vendors' customers are local.

In Table 4c, we can examine the correlations between the different enforcement variables. The correlations are not as high as one would expect. The formal enforcement variables (courts, local government, SIMA) show some correlation, ranging from 0.17 to 0.27 . There is in several cases a negative correlation between the formal and informal enforcement variables, showing that firms that believe strongly in one type of enforcement mechanism (either formal or informal) tend to have less confidence in the other form. Among the informal enforcement variables, the highest correlation (0.57) is between the variables "Other customers would find out about my dispute with a customer" and "Businesses would refuse to deal with a customer unfair to me". There is also substantial 
correlation ( 0.29 to 0.35$)$ between the different variables for the surveyed firm finding out about disputes with others or others finding out about the surveyed firm's disputes.

Table 4c

Correlations of Informal and Formal Enforcement Variables

\begin{tabular}{|c|c|c|c|c|c|c|c|}
\hline & $\begin{array}{c}\text { Other } \\
\text { Customers } \\
\text { Would } \\
\text { Find Out } \\
\text { Disp. } \\
\text { w/my } \\
\text { Cust. }\end{array}$ & $\begin{array}{l}\text { Business } \\
\text { Refuse to } \\
\text { Deal with } \\
\text { Cust. for } \\
\text { Cheating }\end{array}$ & $\begin{array}{l}\text { I Would } \\
\text { Find Out } \\
\text { Dispute } \\
\text { Customer } \\
\text { w/other } \\
\text { Supplier }\end{array}$ & $\begin{array}{c}\text { Other Cust } \\
\text { Would Find } \\
\text { Out } \\
\text { Dispute w/ } \\
\text { my } \\
\text { Supplier }\end{array}$ & $\begin{array}{c}\text { Courts } \\
\text { Effective } \\
\text { in Disp. } \\
\text { Resol. }\end{array}$ & $\begin{array}{l}\text { Local } \\
\text { Gov't } \\
\text { Effective } \\
\text { in Disp. } \\
\text { Resol. }\end{array}$ & $\begin{array}{c}\text { SIMA } \\
\text { Effective } \\
\text { in Disp } \\
\text { Resol. }\end{array}$ \\
\hline $\begin{array}{l}\text { Other Customers Would } \\
\text { Find Out Disp. w/ my Cust. }\end{array}$ & 1.00 & & & & & & \\
\hline $\begin{array}{l}\text { Business Refuse to Deal } \\
\text { with Cust. for Cheating }\end{array}$ & 0.57 & 1.00 & & & & & \\
\hline $\begin{array}{l}\text { I Would Find Out } \\
\text { Dispute Customer w/ } \\
\text { Other Supplier }\end{array}$ & 0.35 & 0.21 & 1.00 & & & & \\
\hline $\begin{array}{l}\text { Other Cust Would Find } \\
\text { Out Dispute w/ My } \\
\text { Supplier }\end{array}$ & 0.02 & 0.12 & 0.29 & 1.00 & & & \\
\hline $\begin{array}{l}\text { Courts Effective in } \\
\text { Dispute Resolution }\end{array}$ & 0.18 & 0.29 & 0.17 & 0.27 & 1.00 & & \\
\hline $\begin{array}{l}\text { Local Gov't Effective in } \\
\text { Disp Resol. }\end{array}$ & -0.11 & -0.09 & -0.16 & 0.02 & 0.17 & 1.00 & \\
\hline $\begin{array}{l}\text { SIMA Effective in Disp } \\
\text { Resol. }\end{array}$ & 0.03 & 0.21 & -0.03 & -0.05 & 0.27 & 0.25 & 1.00 \\
\hline
\end{tabular}

Probit Results: Probability of Offering Trade Credit as Measure of Inter-firm Trust

Table 5 contains the results of probit estimation of variables that affect the likelihood that the interviewed firms offer trade credit to their customers and tobit estimates for the impact of variables on the amount of trade credit offered to customers. ${ }^{23}$

The results for the "lock-in" variables are mixed. One of the variables representing lock-in, that it would take a month or more for customers to find alternate supplies, is insignificant in the regressions. On the other hand, the duration of the trading relationship, which represents both lock-in and information gathering about the customer, is positive and significant at the 10 percent level in the probit regression and at the 5 percent level in the tobit regression. A one-year increase in the duration of the relationship increases the likelihood that a firm offers credit to its customers by about 3.5 percent, and increases by 9 percentage points the proportion of their bill paid with delay. Increasing the duration of the relationship by one standard deviation (from 6.74 to 13.37 years) increases the probability of offering trade credit by about 23 percent.

McMillan and Woodruff note that the duration variable may be biased upward, since both initial credit and duration of a trading relationship may be correlated with the level of initial trust that a firm has in a new customer. The duration variables may also theoretically bias the estimates of the other coefficients. However, repeating the regressions without the duration variables has mostly minor impacts on the coefficient estimates. Of the variables that were significant in the original regressions, only two coefficients (for control variables, $\ln (1+$ age $)$ and the dummy variable for exporters) had noticeable changes in the estimates. These results can also be found in Table 5 .

\footnotetext{
${ }^{23}$ The standard errors are made robust by correcting for the fact that data was collected about two customers from the same firm. The data for two customers of the same firm is considered "clustered" so that standard errors are calculated under the assumption that errors are independent across firms, but not necessarily within firms, in other words that the observations of the customers of the same firm may be correlated.
} 
Obtaining information about customers through a business network appears to have a positive and significant impact, increasing the probability of offering credit by 26 percent and allowing customers to pay 44 percent more of their bill with delay. Also, talking frequently with other suppliers of a customer (another way of measuring a business network) has a significant effect, increasing the likelihood of offering credit by 19 percent.

There is support for the hypothesis that belief in the court system increases the likelihood that trade credit is offered. Firms that believe in the effectiveness of courts are about 30 percent more likely to offer trade credit and permit their customers to pay about 55 percent more of their bill with delay. The variable representing community sanctions (a dummy variable representing the belief of the surveyed firm that other businesses would refuse to deal with a customer who cheated) does not have a significant effect on the decision to offer trade credit.

Exporters are found to be more likely to offer trade credit to their customers and offer more trade credit, but the estimated coefficients are insignificant except for one of the tobit estimates (at the 10 percent level).

An alternate specification of regression Equations 1a and 2a is presented in Table 6. In this specification, different survey questions are used to derive alternate variables for "lock-in," "information and network effects" and "community enforcement." The results are quite similar to the main specification in Table 5 in terms of which categories of variables are significant and the size of the coefficient estimates.

In all regressions, the $\mathrm{R}$-squared of the Tobit regressions is low as compared to the probit model. In other words, the model does better at explaining the likelihood of offering trade credit rather than the amount of trade credit awarded. Given that the amount of trade credit offered to customers is clustered at 0,50 , and 100 percent, this is not surprising. Also, the clustering of the trade credit amounts helps to explain the large magnitudes of the coefficient estimates in the Tobit specifications.

Given the significant differences between the exporter and vendor firms, the main and alternate specifications from Tables 5 and 6 were repeated, but with exporter interaction terms for most of the variables. These results are reported in Appendix 2, Tables A3 and A4. Examining these tables, the significant variables from Tables 5 and 6 maintain their sign and significance but increase in magnitude in Tables A3 and A4 as compared to Tables 5 and $6 .{ }^{25}$ In addition, the exporter interaction terms of the same variables are often of the opposite sign. In other words, the significant results for some of the relational contracting variables in the original specifications in Tables 5 and 6 (business network for information, talking to other producers weekly or monthly) and the role of the courts for enforcing contracts were being driven by the vendor firms. ${ }^{26}$ The exporter interaction terms, while of the opposite sign, are mostly insignificant. It makes sense that the dealings of the exporters with their (international) buyers will have different dynamics than those of the vendors, where both supplier and customer are located in close proximity. In particular, it makes sense that the role of Pakistani courts is downplayed for the exporters in their relationships with customers based abroad. $^{27}$

\footnotetext{
${ }^{25}$ An exception is duration. When the exporter interactions are included for duration, all duration variables become insignificant. There were not major differences in duration between exporters and vendors, and so these specifications were not reported.

${ }^{26}$ Similar results were achieved when the sample excluded firms with more than 50 employees and firm with more than 100 employees. Only the exporter*business refuse (informal enforcement) variable changed signs when firms with more than 100 employees was included.

${ }^{27}$ In the specifications reported here, the Exporter*court variable is negative but insignificant. In some other (very similar) specifications, it gains statistical significance.
} 
Table 5

Regressions on Trade Credit to Customers, Marginal Effects, Probit and Tobit, Main Specification, Clustered Errors

\begin{tabular}{|c|c|c|c|c|}
\hline & Probit & Tobit & $\begin{array}{l}\text { Probit } \\
\text { (without } \\
\text { Duration) } \\
\end{array}$ & $\begin{array}{c}\text { Tobit } \\
\text { (without } \\
\text { Duration) } \\
\end{array}$ \\
\hline \multicolumn{5}{|l|}{ Lock-in } \\
\hline $\begin{array}{l}\text { Would Take Customer More Than } \\
\text { a Month to Find Alternate Supply } \\
\text { Information/lock-in }\end{array}$ & $\begin{array}{l}-0.069 \\
(-0.58)\end{array}$ & $\begin{array}{c}0.49 \\
(0.02)\end{array}$ & $\begin{array}{l}-0.074 \\
(-0.68)\end{array}$ & $\begin{array}{c}-5.37 \\
(-0.21)\end{array}$ \\
\hline Duration of Relationship (Years) & $\begin{array}{l}0.036 \\
(1.91)^{+}\end{array}$ & $\begin{array}{c}9.22 \\
(2.08)^{*}\end{array}$ & & \\
\hline Duration-squared & $\begin{array}{c}-0.00088 \\
(-1.09)\end{array}$ & $\begin{array}{l}-0.24 \\
(-1.24)\end{array}$ & & \\
\hline \multicolumn{5}{|l|}{$\begin{array}{l}\text { Information / } \\
\text { Network Effects }\end{array}$} \\
\hline $\begin{array}{l}\text { Info. About Customer Through } \\
\text { Business Network } \\
\text { Talk to Other Producers At Least } \\
\text { Monthly }\end{array}$ & $\begin{array}{c}0.26 \\
(2.59)^{*} \\
0.19 \\
(2.09)^{*}\end{array}$ & $\begin{array}{c}\mathbf{4 4 . 4 4} \\
(2.10) * \\
27.97 \\
(1.37)\end{array}$ & $\begin{array}{c}0.28 \\
(2.81)^{* *} \\
0.18 \\
(2.03)^{*}\end{array}$ & $\begin{array}{c}\mathbf{4 6 . 4 5} \\
(\mathbf{2 . 1 1})^{*} \\
23.36 \\
(1.12)\end{array}$ \\
\hline \multicolumn{5}{|l|}{ Enforcement } \\
\hline $\begin{array}{l}\text { Businesses Would Refuse to Deal } \\
\text { with Customer who Cheated } \\
\text { Manufacturer }\end{array}$ & $\begin{array}{l}-0.031 \\
(-0.36)\end{array}$ & $\begin{array}{l}-25.41 \\
(-1.45)\end{array}$ & $\begin{array}{l}-0.027 \\
(-0.34)\end{array}$ & $\begin{array}{c}-25.01 \\
(-1.51)\end{array}$ \\
\hline Belief in Court System & $\begin{array}{c}0.30 \\
(3.23)^{* * *}\end{array}$ & $\begin{array}{l}55.75 \\
(2.44)^{*}\end{array}$ & $\begin{array}{c}0.31 \\
(3.63)^{* *}\end{array}$ & $\begin{array}{c}\mathbf{5 5 . 0 4} \\
(\mathbf{2 . 4 5})^{*}\end{array}$ \\
\hline \multicolumn{5}{|l|}{ Controls } \\
\hline Ln(1+Age $)$ & $\begin{array}{c}-0.16 \\
(-2.86)^{* *}\end{array}$ & $\begin{array}{l}-25.45 \\
(-1.94)+\end{array}$ & $\begin{array}{c}-0.085 \\
(-1.67)+\end{array}$ & $\begin{array}{l}-6.12 \\
(-0.56)\end{array}$ \\
\hline Ln(Employment) & $\begin{array}{l}0.081 \\
(2.31)^{*}\end{array}$ & $\begin{array}{l}22.67 \\
(2.41)^{*}\end{array}$ & $\begin{array}{l}0.079 \\
(2.42)^{*}\end{array}$ & $\begin{array}{c}24.45 \\
(2.73)^{* *}\end{array}$ \\
\hline Export Dummy & $\begin{array}{l}0.059 \\
(0.58)\end{array}$ & $\begin{array}{c}41.54 \\
(1.82)+\end{array}$ & $\begin{array}{l}0.033 \\
(0.33)\end{array}$ & $\begin{array}{l}33.31 \\
(1.50)\end{array}$ \\
\hline Observations & 132 & 132 & 132 & 132 \\
\hline R-Squared & 0.18 & 0.043 & 0.14 & 0.03 \\
\hline $\begin{array}{l}\bar{I}^{R} \text { Relative Amount of } \\
\text { Information }^{24} \\
\text { in Prediction }^{24}\end{array}$ & 0.26 & $\begin{array}{c}\text { Not } \\
\text { applicable }\end{array}$ & 0.23 & $\begin{array}{c}\text { Not } \\
\text { applicable }\end{array}$ \\
\hline Chi-Squared & $\begin{array}{c}31.69 \\
(\mathrm{dof}=10)\end{array}$ & $\begin{array}{c}24.09 \\
(\mathrm{dof}=10)\end{array}$ & $\begin{array}{c}24.93 \\
(\mathrm{dof}=8)\end{array}$ & $\begin{array}{c}16.79 \\
(\mathrm{dof}=8)\end{array}$ \\
\hline Prob $>$ Chi-Squared & 0.0005 & 0.0074 & 0.0016 & 0.032 \\
\hline
\end{tabular}

Robust $z$ statistics in parentheses, ** significant at 1 percent, * significant at 5 percent, + significant at 10 percent.

${ }^{24} I^{R}$, or the "relative amount of information in prediction" for models with qualitative dependent variables was developed by Betancourt and Clague (1981). Put simply, it assesses the amount of additional information imparted by the inclusion of explanatory variables to the model (i.e., the introduction of a theory) relative to the amount of information already contained in the sample proportions. It helps to deal with some of the undesirable properties of traditional R2 measures as they are applied to qualitative dependent variable models, for example that there cannot be a decomposition of total variation and questions about the correct upper-bound for binary-choice statistics. 
Table 6

Regressions on Trade Credit to Customers, Marginal Effects, Probit and Tobit, Alternate Specification, Clustered Errors

\begin{tabular}{|c|c|c|c|c|}
\hline & Probit & Tobit & $\begin{array}{c}\text { Probit } \\
\text { (without } \\
\text { Duration) } \\
\end{array}$ & $\begin{array}{c}\text { Tobit } \\
\text { (without } \\
\text { Duration) } \\
\end{array}$ \\
\hline \multicolumn{5}{|l|}{ Lock-in } \\
\hline $\begin{array}{l}\text { Would Take Customer Less } \\
\text { than a Week to Find Alternate } \\
\text { Supply }\end{array}$ & $\begin{array}{c}0.12 \\
(1.36)\end{array}$ & $\begin{array}{l}14.18 \\
(0.91)\end{array}$ & $\begin{array}{c}0.11 \\
(1.22)\end{array}$ & $\begin{array}{l}14.26 \\
(0.87)\end{array}$ \\
\hline $\begin{array}{l}\text { Would Take Customer More } \\
\text { Than a Month to Find Alternate } \\
\text { Supply }\end{array}$ & $\begin{array}{l}-0.042 \\
(-0.34)\end{array}$ & $\begin{array}{l}1.32 \\
(0.05)\end{array}$ & $\begin{array}{l}-0.051 \\
(-0.45)\end{array}$ & $\begin{array}{l}-3.29 \\
(-0.12)\end{array}$ \\
\hline \multicolumn{5}{|l|}{ Information / Lock-in } \\
\hline $\begin{array}{l}\text { Duration of Relationship } \\
\text { (Years) }\end{array}$ & $\begin{array}{c}0.034 \\
(1.94)+\end{array}$ & $\begin{array}{c}8.82 \\
(2.07) *\end{array}$ & & \\
\hline Duration-squared & $\begin{array}{l}-0.001 \\
(-1.13)\end{array}$ & $\begin{array}{l}-0.22 \\
(-1.20)\end{array}$ & & \\
\hline \multicolumn{5}{|l|}{$\begin{array}{l}\text { Information/ } \\
\text { NetworkEffects }\end{array}$} \\
\hline $\begin{array}{l}\text { Info. About Customer Through } \\
\text { Business Network } \\
\text { Talk to Other Producers } \\
\text { At Least Weekly }\end{array}$ & $\begin{array}{c}0.24 \\
(2.39)^{*} \\
0.20 \\
(2.54)^{* *}\end{array}$ & $\begin{array}{l}\mathbf{4 1 . 2 2} \\
(1.96)^{*} \\
28.30 \\
(1.54)\end{array}$ & $\begin{array}{c}0.25 \\
(2.58)^{* *} \\
0.20 \\
(2.58)^{* *}\end{array}$ & $\begin{array}{c}\mathbf{4 3 . 8 3} \\
(\mathbf{2 . 0 2})^{*} \\
27.72 \\
(1.47)\end{array}$ \\
\hline \multicolumn{5}{|l|}{ Enforcement } \\
\hline $\begin{array}{l}\text { Customers Would Find Out } \\
\text { About Dispute with Another } \\
\text { Customer }\end{array}$ & $\begin{array}{l}-0.073 \\
(-0.90)\end{array}$ & $\begin{array}{l}-17.42 \\
(-1.06)\end{array}$ & $\begin{array}{l}-0.073 \\
(-0.92)\end{array}$ & $\begin{array}{l}-15.96 \\
(-0.98)\end{array}$ \\
\hline Belief in Court System & $\begin{array}{c}0.29 \\
(3.16)^{* *}\end{array}$ & $\begin{array}{l}49.21 \\
(2.13)^{*}\end{array}$ & $\begin{array}{c}0.30 \\
(3.49)^{* *}\end{array}$ & $\begin{array}{c}48.43 \\
(2.09)^{*}\end{array}$ \\
\hline \multicolumn{5}{|l|}{ Controls } \\
\hline Ln(1+Age $)$ & $\begin{array}{c}-0.16 \\
(-2.85)^{* *}\end{array}$ & $\begin{array}{l}-21.57 \\
(-1.65)+\end{array}$ & $\begin{array}{l}-0.079 \\
(-1.62)\end{array}$ & $\begin{array}{l}-2.07 \\
(-0.18)\end{array}$ \\
\hline Ln(Employment) & $\begin{array}{c}0.068 \\
(1.65)+\end{array}$ & $\begin{array}{c}19.89 \\
(1.95)+\end{array}$ & $\begin{array}{c}0.068 \\
(1.78)+\end{array}$ & $\begin{array}{c}21.71 \\
(2.23)^{*}\end{array}$ \\
\hline Export Dummy & $\begin{array}{l}0.13 \\
(1.35)\end{array}$ & $\begin{array}{l}46.87 \\
(2.04) *\end{array}$ & $\begin{array}{l}0.099 \\
(1.06)\end{array}$ & $\begin{array}{l}38.95 \\
(1.69)+\end{array}$ \\
\hline Observations & 132 & 132 & 132 & 132 \\
\hline R-Squared & 0.21 & 0.044 & 0.17 & 0.03 \\
\hline $\begin{array}{l}\bar{I}^{R} \text { Relative Amount of } \\
\text { Information in Prediction }\end{array}$ & 0.30 & $\begin{array}{c}\text { Not } \\
\text { applicable }\end{array}$ & 0.23 & $\begin{array}{l}\text { Not } \\
\text { applicable }\end{array}$ \\
\hline Chi-Squared & $\begin{array}{c}36.58 \\
(\mathrm{dof}=11)\end{array}$ & $\begin{array}{c}26.12 \\
(\mathrm{dof}=11)\end{array}$ & $\begin{array}{c}33.45 \\
(\mathrm{dof}=9)\end{array}$ & $\begin{array}{c}17.86 \\
(\mathrm{dof}=9)\end{array}$ \\
\hline Prob $>$ Chi-Squared & 0.0001 & 0.006 & 0.0001 & 0.037 \\
\hline
\end{tabular}


There is also some evidence of supplier lock-in driving the provision of trade credit. In Table A4, the variable representing that it would take less than a week for the supplier to find alternate input supplies has a positive coefficient that is significant at the 10 percent level. Also, some other specifications (not reported here) explicitly included a supplier lockin variable, signifying that it would be difficult for the firm to locate an alternate customer. This variable had a positive sign, and was sometimes significant. In other words, these results indicate that firms appear to be offering trade credit in part to keep customers' business.

\section{Replicating McMillan and Woodruff Specifications}

We also estimate a tobit model using a similar specification to McMillan and Woodruff's (1999) specifications for firms in Vietnam. These results can be found in Table A1 (in Appendix 2). The coefficients with the most similar results are for the duration variable, where estimates of the effect of increasing the length of the relationship on the amount of trade credit offered for both Sialkot and Vietnam are around 7-8 percent. Also similar in magnitude is the replication of McMillan and Woodruff's first regression for the effect of information obtained through a business network, with estimates of 26 and 20 percent in Sialkot and Vietnam respectively. For the effect of lock-in, age, employment and "price being set by the relationship with customer", the estimated coefficients have the same signs as McMillan and Woodruff, but are different in magnitude.

\section{Robustness}

Additional regressions (Table A2, in Appendix 2) test for the robustness of the relational contracting results against alternate explanations for trade credit offered in the literature. A clear hypothesis does not arise with respect to the size or age of firms and trade credit. If trade credit serves as a way to assure quality, then larger and older firms should offer less trade credit since they should have a lower variance in quality. ${ }^{28}$ On the other hand, if larger and older firms have better access to formal credit sources, then they should offer more trade credit on average. ${ }^{29}$ Trade credit may also be a price discrimination mechanism. ${ }^{30}$ McMillan and Woodruff (1999) found for Vietnam that, on average, larger and older firms offered less trade credit to their customers. Our results are mixed; smaller and older firms offer less trade credit to their customers on average.

A firm that has access to credit from formal sources, either from a bank or a credit association, may be more likely to offer trade credit, because it is less credit constrained. However, the regressions in Table A2 show that access to formal credit does not affect either whether trade credit is offered or the amount. The average percentage of trade credit received from suppliers, another source of credit that may loosen credit constraints, has a small but positive effect on the probability that firms offer credit to their customers (less than one percent) and on the amount of credit offered (also less than one percent).

In order to test the price discrimination hypothesis, McMillan and Woodruff (1999) used a dummy variable representing when firms set their price based on the relationship with the customer. Since only one percent of the firms in our sample answered this question affirmatively, this variable could not be included in our specifications.

\footnotetext{
${ }^{28}$ See Long, Malitz, and Ravid (1993), Deloof and Jegers (1996).

${ }^{29}$ See Peterson and Rajan (1997).

${ }^{30}$ See Petersen and Rajan (1997). The discussion of alternate trade credit hypotheses was taken from McMillan and Woodruff(1999).
} 
Two other variables included in the robustness regressions are a social network variable and an interaction variable between exporters and belief in the court system. The coefficient on the social network variable, in contrast to the business network variable, is not significant. The joint "court*exporter" variable is also not significant. In the tobit regression, inclusion of this interaction variable has a minor impact on coefficient estimate of the original variable for belief in the courts, but it is still significant at the 5 percent level. The likely explanation is that the exporters are unlikely to be able to rely on local courts for dispute resolution with international customers.

We also estimate the main specification using an alternate estimation technique to correct for the survey sampling method, taking into account the stratification of the sample (between exporters and non-exporters) and the under-representation of vendors in the sample. ${ }^{31}$ Among the significant variables, the probit estimates with corrections for the survey sampling technique are larger in magnitude and more significant than the estimates that only corrected for clustered errors (except in one case). Among the significant variables in the tobit regressions, the estimates are more significant when corrections are made for the sampling technique, but are smaller in magnitude (except the dummy variable that the firm communicates with other firms at least monthly). The magnitudes and significance of the estimates calculated with this method are in general quite high, leading us to question whether they are in fact realistic.

We also re-estimate the main specifications in Table 5 using different samples. ${ }^{32}$ In one case, a slightly smaller sample where the only observations that are included are those that have two customers per firm. The results are very similar to those in Table 5, except that some coefficient estimates are slightly larger (in absolute value) and somewhat more significant. We also estimate the main specification for only the exporters in the sample. Except for duration of the relationship and employment, most of the variables lose significance when only the exporter observations are used as compared to the full sample that includes the vendor firms. In addition, the effect of increasing the duration of the trading relationship by one year is larger in magnitude in the exporter-only sample, but only significant at the 10 percent level. The main specification in Table 5 was also done on samples of firms with 100 employees or less and 50 employees or less. The level of statistical significance falls with the number of observations, but the results are qualitatively the same.

\section{CONCLUSIONS}

Several interesting results have been obtained regarding relational contracting as well as the prospects for direct marketing by clustered firms. It was originally speculated that networks, rather than the lock-in of individual customers, would be the predominant form of contract enforcement in a cluster environment. However, similar to McMillan and Woodruff (1999), both types of variables were significant in the regressions of trade credit offered to customers. Since firms give more trade credit (and are more likely to give credit) when relationships are of longer duration, there is some evidence of lock-in as a tool for contract enforcement. Business networks, that may be used to gather information about the reliability of customers or for social sanction, are also found to be significant correlates of inter-firm trust; firms that obtain information through business networks are more likely to offer trade credit (and offer more trade credit) to their customers. Finally, we found that firms

\footnotetext{
${ }^{31}$ Results not reported, but available upon request.

${ }^{32}$ Results not reported, but available upon request.
} 
are more likely to offer trade credit and to offer more trade credit to their customers when firms believe that the court system can help to enforce contracts.

Without effective contract enforcement mechanisms of some kind, moral hazard can jeopardize the existence of transactions other than those taking place on the spot market. The results of this study, along with the previous results of Johnson, McMillan, and Woodruff (2002), confirm the important role of a formal system of contract enforcement (specifically the court system) in supporting contract enforcement, which in turn helps to reduce transaction costs. Johnson, McMillan, and Woodruff (2002) found that firms that believed in the court system were 8 percent more likely to offer trade credit and allowed customers to pay approximately 5.5 percent more of their bill after delivery. In our study, we found that belief in the effectiveness of the court system raised the probability of offering trade credit by 30 percent, and increasing the percentage of bill paid after delivery by 50 percentage points.

We find however that, other than duration (which seems to be common across the firms), some of these results, particularly the role of business networks for information and the role of courts, are (logically) restricted to the vendor segment, whose customers are local.

Industrial clusters provide employment for large numbers of people in developing countries, and have become significant exporters. Case studies highlighting the successes of developing country clusters in these respects have led to enthusiasm on the part of development practitioners about the prospects of clustering as a strategy to promote private sector development and reduce poverty. On the other hand, our relational contracting results are qualitatively (and in some cases quantitatively) similar to those obtained in studies of non-clustered firms. ${ }^{33}$ Furthermore, social network-based relationships in clusters have been shown to have distortionary effects, as documented by Ilias (2001) and Banerjee and Munshi (2000). Therefore, policies to promote the development of industrial clusters should consider both the benefits and the drawbacks of clustering, and incorporate the lessons learned from these studies.

${ }^{33}$ This is only a tentative conclusion based on a comparison of the coefficient estimates of similar regressions conducted of clustered (Sialkot, this study) and non-clustered firms [Vietnam, McMillan, and Woodruff (1999)]. We cannot directly compare the magnitudes of coefficients because there was not a joint regression of clustered and non-clustered firms. Conclusive results comparing contract enforcement of clustered versus nonclustered firms would require further study. 
Appendices

\section{APPENDIX 1 \\ DATA CLEANING AND DESCRIPTION OF SAMPLE}

\section{Data Cleaning}

When the interviewer went to the cluster to begin interviewing firms, she found that only about 180 of the 220 exporting firms that were listed by SIMA (the local business association) as surgical instrument manufacturers were actually in operation at the time of the survey. Of the exporter firms in operation, 99 returned the surveys (by mail), out of which 76 were actually filled out leading to a response rate of 43 percent among the exporters. The interviewer then met with 47 vendor firms in the villages surrounding Sialkot, where the cottage industry is located, to conduct face-to-face interviews.

Data was collected on 123 firms. This meant that there was potentially information on 246 customers and 246 suppliers. However, some of the surveys were incomplete and several observations had to be dropped in order to have a balanced data set.

\section{Customer Credit Sample}

Once the dataset was cleaned and balanced, 132 observations remained for the customer credit regressions representing 72 unique firms in the survey. For 60 firms (32 exporters and 28 vendors) there were two observations per firm (representing their oldest and newest customers). For 12 firms ( 7 exporters and 5 vendors) there was only adequate information on one of their customers. These 12 firms only provided enough information on the variables of interest for one of their customers, and therefore the other customer had to be dropped. For the 7 exporters where there was only sufficient data on one customer, 5 had data on their oldest customer only and 2 had enough data only on their newest customer. For the 5 vendors where there was only sufficient data on one customer, 3 had data on their oldest customer only and 2 had enough data only on their newest customer.

\section{Supplier Credit Sample}

Once the dataset was cleaned and balanced, 113 observations remained for the supplier credit regressions representing 63 unique firms in the survey. For 50 firms (31 exporters and 19 vendors) there were two observations per firm (representing their oldest and newest suppliers) and for 13 firms (7 exporters and 6 vendors) there was only adequate information on one of their suppliers. These 13 firms only provided enough information on the variables of interest for one of their suppliers, and therefore the other supplier had to be dropped. For the 7 exporters where there was only data on one supplier, 6 had sufficient data on their oldest supplier only and 1 had enough data only on their newest supplier. For the 6 vendors where there was only data on one supplier, 5 had data on their oldest supplier and 1 had sufficient data only on their newest supplier.

\section{Comparison of Customer Credit and Supplier Credit Samples}

Since the number of observations was limited, the samples were cleaned separately for the customer credit regressions and the supplier credit regressions. Comparing the two samples, 90 of the same observations representing 53 of the same firms were included in the two data sets. 


\section{APPENDIX 2 ADDITIONAL REGRESSION AND DATA TABLES}

\begin{tabular}{|c|c|c|c|c|}
\hline \multicolumn{5}{|c|}{$\begin{array}{c}\text { Table A1 } \\
\text { Regressions on Trade Credit to Customers, Marginal }\end{array}$} \\
\hline & $\begin{array}{c}\text { Tobit } \\
\text { (sim. to Col. } 1 \\
\text { of McM-W) }\end{array}$ & $\begin{array}{c}\text { Tobit } \\
(\mathrm{Co} 1.1 \text { of } \\
\mathrm{McM}-\mathrm{W})^{34}\end{array}$ & $\begin{array}{c}\text { Tobit } \\
\text { (sim. to Col. } 3 \\
\text { of } \mathrm{McM}-\mathrm{W} \text { ) }\end{array}$ & $\begin{array}{l}\text { Tobit } \\
\text { (Col. } 3 \text { of } \\
\text { McM-W) }\end{array}$ \\
\hline \multicolumn{5}{|l|}{ Lock-in } \\
\hline Would Take Customer Less than a & -3.64 & & -7.07 & \\
\hline Week to Find Alternate Supply & $(-0.19)$ & & $(-0.43)$ & \\
\hline Would Take Cust. More Than a & 22.26 & & -5.78 & \\
\hline Month to Find Alt. Supply & $(0.75)$ & & $(-0.20)$ & \\
\hline No. Similar Manufacturers w/in $1 \mathrm{~km}$ & & $\begin{array}{c}-0.7 \\
(1.66)+\end{array}$ & & $\begin{array}{l}-1.1 \\
(2.54)^{*}\end{array}$ \\
\hline Most Important Competitor w/in $1 \mathrm{~km}$ & & $\begin{array}{l}-13 \\
(2.46)^{*}\end{array}$ & & $(2.92)^{* * *}$ \\
\hline \multicolumn{5}{|l|}{ Information/Lock-in } \\
\hline Duration of Relationship (Years) & $\begin{array}{c}7.32 \\
(1.64)+\end{array}$ & $\begin{array}{c}8 \\
(2.96)^{* *}\end{array}$ & $\begin{array}{l}8.63 \\
(2.01)^{*}\end{array}$ & $\begin{array}{c}7 \\
(2.51)^{*}\end{array}$ \\
\hline Duration-squared & $\begin{array}{l}-0.19 \\
(-0.96)\end{array}$ & $\begin{array}{l}-0.5 \\
(2.15)^{*}\end{array}$ & $\begin{array}{l}-0.23 \\
(.)\end{array}$ & $\begin{array}{c}-0.4 \\
(1.74)^{+}\end{array}$ \\
\hline \multicolumn{5}{|l|}{ Info./Network Effects } \\
\hline Info. About Customer Through & 26.17 & 20 & 27.79 & 10 \\
\hline Business Network & $(1.32)$ & $(3.36)^{* * *}$ & (1.49) & $(1.99)^{*}$ \\
\hline $\begin{array}{l}\text { At Least Monthly } \\
\text { Info. About Customer Through }\end{array}$ & -0.55 & 4 & 16.84 & $\begin{array}{l}(2.63)^{* * *} \\
-8\end{array}$ \\
\hline Social Network & $(-0.02)$ & $(0.60)$ & $(0.67)$ & $(1.34)$ \\
\hline \multicolumn{5}{|l|}{ Controls } \\
\hline $\begin{array}{l}\text { Price Set by Relationship with } \\
\text { Customer }\end{array}$ & & & $\begin{array}{c}50.62 \\
(1.77)^{+}\end{array}$ & $\begin{array}{c}2 \\
(0.53)\end{array}$ \\
\hline Customer is Retailer/Wholesaler & & & & $\begin{array}{c}7 \\
(1.62)\end{array}$ \\
\hline Ln(1+Age) & & & $\begin{array}{l}-20.28 \\
(-1.47)\end{array}$ & $\begin{array}{c}-9 \\
(1.76)+\end{array}$ \\
\hline Ln(Employment) & & & $\begin{array}{c}26.52 \\
(1.95)+\end{array}$ & $\begin{array}{c}2 \\
(0.98)\end{array}$ \\
\hline Manufacturer Receives Bank Credit & & & $\begin{array}{l}14.38 \\
(0.44)\end{array}$ & $\begin{array}{l}-2 \\
(0.36)\end{array}$ \\
\hline $\begin{array}{l}\text { Avg. \% of Bill Paid with Delay to } \\
\text { Sunpliers }\end{array}$ & & & 0.62 & 40 \\
\hline Observations & 132 & 224 & 132 & 224 \\
\hline Chi-Squared & 8.89 & 73.5 & 32.50 & 134.5 \\
\hline Prob $>$ Chi-Squared & 0.18 & $<0.001$ & 0.0003 & $<0.001$ \\
\hline
\end{tabular}

${ }^{34}$ We have converted McMillan and Woodruff's results from decimals to percentages to be more easily comparable to our results, which accounts for the lower degree of accuracy for those results. 
Table A2

Customer Credit Robustness Check, Marginal Effects, Main Specification, Clustered Errors

\begin{tabular}{|c|c|c|}
\hline & Probit & Tobit \\
\hline \multicolumn{3}{|l|}{ Lock-in } \\
\hline Would Take Customer More Than a & -0.091 & -6.33 \\
\hline Month to Find Alternate Supply & $(-0.77)$ & $(-0.24)$ \\
\hline \multicolumn{3}{|l|}{ Information/Lock-in } \\
\hline \multirow[t]{2}{*}{ Duration of Relationship (Years) } & 0.035 & 9.63 \\
\hline & $\begin{array}{c}(2.02)^{*} \\
-0.0009\end{array}$ & $\begin{array}{l}(2.23)^{*} \\
-0.26\end{array}$ \\
\hline Duration-squared & $(-1.25)$ & $(-1.43)$ \\
\hline \multicolumn{3}{|l|}{ Information /Network Effects } \\
\hline Info. About Customer Through & 0.25 & 41.12 \\
\hline Business Network & $(2.68)^{* *}$ & $(1.92)+$ \\
\hline Info. About Customer Through & 0.014 & 13.11 \\
\hline Social Network & $(0.14)$ & $(0.57)$ \\
\hline $\begin{array}{l}\text { Talk to other Suppliers of Customer } \\
\text { At Least Monthly }\end{array}$ & 0.12 & 23.61 \\
\hline \multicolumn{3}{|l|}{ Enforcement } \\
\hline \multirow{2}{*}{$\begin{array}{l}\text { Businesses Would Refuse to Dealwith } \\
\text { Customer Who Cheated Manufacturer }\end{array}$} & -0.066 & -28.51 \\
\hline & $(-0.75)$ & $(-1.61)$ \\
\hline \multirow[t]{2}{*}{ Belief in Court System } & 0.27 & 37.95 \\
\hline & $(2.51)^{*}$ & $(\mathbf{2 . 0 0})^{*}$ \\
\hline Export Dummy*Belief in Courts & $\begin{array}{c}0.14 \\
(0.79)\end{array}$ & 55.57 \\
\hline \multirow{2}{*}{\multicolumn{3}{|c|}{ Controls }} \\
\hline & & \\
\hline Ln (1+Age) & $(-3.33) * *$ & $\begin{array}{l}-26.92 \\
(-2.06)^{*}\end{array}$ \\
\hline \multirow{2}{*}{ Ln (Employment) } & 0.053 & 16.72 \\
\hline & (1.14) & $(1.45)$ \\
\hline \multirow{2}{*}{ Receive Bank Credit } & -0.027 & 13.34 \\
\hline & $(-0.22)$ & $(0.40)$ \\
\hline \multirow{2}{*}{$\%$ Trade Credit Received by Supplier } & 0.0046 & 0.79 \\
\hline & $(4.49)^{* *}$ & $(3.04)^{* * *}$ \\
\hline Export Dummy & 0.16 & 49.21 \\
\hline Observations & $(1.78)+$ & $(1.78)+$ \\
\hline & 132 & 132 \\
\hline Chi-Squared & $\begin{array}{l}46.09 \\
\operatorname{dof}=14\end{array}$ & $\begin{array}{l}33.84 \\
d o f=14\end{array}$ \\
\hline Prob $>$ Chi-Squared & $<0.0001$ & 0.0022 \\
\hline
\end{tabular}


Table A3

Main Specification, with Exporter Interactions

Number of Observations: 132

Pseudo $R 2=0.265$

\begin{tabular}{|c|c|c|}
\hline & $\begin{array}{c}\text { Probit: } \\
\text { Marginal } \\
\text { Effect }\end{array}$ & Z-Stat \\
\hline \multicolumn{3}{|l|}{ Lock-in } \\
\hline Would Take Customer More Than a & & \\
\hline Month to Find Alternate Supply & -0.178 & -1.25 \\
\hline \multicolumn{3}{|l|}{ Information / Lock-in } \\
\hline Duration of Relationship (Years) & $0.059 *$ & 2.54 \\
\hline Duration-squared & -0.002 & -1.61 \\
\hline \multicolumn{3}{|l|}{ Information / Network Effects } \\
\hline $\begin{array}{l}\text { Info. About Customer Through } \\
\text { Business Network }\end{array}$ & $0.530 * *$ & 2.70 \\
\hline $\begin{array}{l}\text { Talk to other Producers At Least Monthly } \\
\text { Exp*Info. About Customer Through }\end{array}$ & $0.601 * *$ & 2.83 \\
\hline Business Network & -0.441 & -1.60 \\
\hline $\begin{array}{l}\text { Exp*Talk to other Producers } \\
\text { At Least Monthly }\end{array}$ & $-0.623 *$ & -2.54 \\
\hline \multicolumn{3}{|l|}{ Enforcement } \\
\hline Customer Who Cheated Manufacturer & -0.292 & -1.38 \\
\hline $\begin{array}{l}\text { Belief in Court System } \\
\text { Exp*Businesses Would Refuse to Deal }\end{array}$ & $0.445 * *$ & 2.80 \\
\hline $\begin{array}{l}\text { with Customer Who Cheated } \\
\text { Manufacturer }\end{array}$ & 0.264 & 1.12 \\
\hline Exp*Belief in Court System & -0.342 & -1.26 \\
\hline \multicolumn{3}{|l|}{ Controls } \\
\hline Ln(1+Age $)$ & $-0.641 * *$ & -4.33 \\
\hline Ln(Employment) & $0.328 *$ & 2.34 \\
\hline Exp*Ln(1+Age $)$ & $0.563^{* *}$ & 3.68 \\
\hline Exp*Ln(Employment) & -0.224 & -1.60 \\
\hline
\end{tabular}


Table A4

Alternate Specification, with Exporter Interactions

Number of Observations: 132

Pseudo R2 $=0.296$

\begin{tabular}{|c|c|c|}
\hline & $\begin{array}{c}\text { Probit: } \\
\text { Marginal } \\
\text { Effects }\end{array}$ & Z-Stat \\
\hline \multicolumn{3}{|l|}{ Lock-in } \\
\hline $\begin{array}{l}\text { Would Take Customer Less Than a Week to } \\
\text { Find Alternate Supply }\end{array}$ & $0.260+$ & 1.80 \\
\hline $\begin{array}{l}\text { would Take Customer More Than a Month to } \\
\text { Find Alternate Supply }\end{array}$ & -0.079 & -0.53 \\
\hline \multicolumn{3}{|l|}{ Information / Lock-in } \\
\hline Duration of Relationship (Years) & $0.055 *$ & 2.31 \\
\hline Duration-squared & -0.001 & -1.42 \\
\hline \multicolumn{3}{|l|}{ Information / Network Effects } \\
\hline $\begin{array}{l}\text { Info. About Customer Through Business } \\
\text { Network }\end{array}$ & $0.528 * *$ & 2.64 \\
\hline Talk to other Producers At Least Weekly & $0.608 * *$ & 2.63 \\
\hline $\begin{array}{l}\text { Exp*Info. About Customer Through Business } \\
\text { Network }\end{array}$ & -0.409 & -1.42 \\
\hline $\begin{array}{l}\text { Exp*Talk to other Producers At Least } \\
\text { Weekly }\end{array}$ & $-0.626 *$ & -2.45 \\
\hline \multicolumn{3}{|l|}{ Enforcement } \\
\hline $\begin{array}{l}\text { Customers would Find Out About Dispute } \\
\text { with Another Customer }\end{array}$ & -0.088 & -0.38 \\
\hline Belief in Court System & $0.448 *$ & 2.35 \\
\hline $\begin{array}{l}\text { Exp*Customers would Find Out About } \\
\text { Dispute with Another Customer }\end{array}$ & 0.121 & 0.46 \\
\hline Exp*Belief in Court System & -0.380 & -1.25 \\
\hline \multicolumn{3}{|l|}{ Controls } \\
\hline $\operatorname{Ln}(1+$ Age $)$ & $-0.588 * *$ & -3.85 \\
\hline Ln(Employment) & $0.243+$ & 1.77 \\
\hline $\operatorname{Exp}^{*} \operatorname{Ln}(1+$ Age $)$ & $0.511 * *$ & 3.04 \\
\hline Exp*Ln(Employment) & -0.138 & -1.01 \\
\hline
\end{tabular}


Table A5

Provision and Receipt of Trade Credit

\begin{tabular}{|c|c|c|c|c|c|}
\hline \multicolumn{6}{|c|}{ EXPORTERS (53 Firms) } \\
\hline & $\begin{array}{l}\text { Give to Old } \\
\text { Customer } \\
\text { (only) }\end{array}$ & $\begin{array}{l}\text { Give to New } \\
\text { Customer } \\
\text { (only) }\end{array}$ & $\begin{array}{c}\text { Give to } \\
\text { Neither } \\
\text { Customer }\end{array}$ & $\begin{array}{l}\text { Give to Both } \\
\text { Customers }\end{array}$ & Total \\
\hline $\begin{array}{l}\text { Receive from Old } \\
\text { Supplier(only) }\end{array}$ & 2 & 0 & 0 & 0 & 2 \\
\hline $\begin{array}{l}\text { Receive from New } \\
\text { Supplier(only) }\end{array}$ & 1 & 0 & 2 & 0 & 3 \\
\hline $\begin{array}{l}\text { Receive from Neither } \\
\text { Supplier }\end{array}$ & 4 & 10 & 8 & 4 & 26 \\
\hline $\begin{array}{l}\text { Receive from Both } \\
\text { Suppliers }\end{array}$ & 8 & 1 & 6 & 7 & 22 \\
\hline Total & 15 & 11 & 16 & 11 & $\begin{array}{l}\text { Out of } 53 \text { exporters, } \\
37 \text { give trade credit, } \\
\text { and } 27 \text { receive trade } \\
\text { credit. }\end{array}$ \\
\hline \multicolumn{6}{|c|}{ VENDORS (42 Firms) } \\
\hline & $\begin{array}{l}\text { Give to Old } \\
\text { Customer } \\
\text { (only) }\end{array}$ & $\begin{array}{l}\text { Give to New } \\
\text { Customer } \\
\text { (only) }\end{array}$ & $\begin{array}{l}\text { Give to } \\
\text { Neither } \\
\text { Customer }\end{array}$ & $\begin{array}{l}\text { Give to Both } \\
\text { Customers }\end{array}$ & Total \\
\hline $\begin{array}{l}\text { Receive from Old } \\
\text { Suppliers (only) }\end{array}$ & 3 & 0 & 1 & 0 & 4 \\
\hline $\begin{array}{l}\text { Receive from New } \\
\text { Suppliers (only) }\end{array}$ & 0 & 0 & 2 & 0 & 2 \\
\hline $\begin{array}{l}\text { Receive from Neither } \\
\text { Supplier }\end{array}$ & 1 & 0 & 2 & 0 & 3 \\
\hline $\begin{array}{l}\text { Receive from Both } \\
\text { Suppliers }\end{array}$ & 3 & 3 & 7 & 20 & 33 \\
\hline Total & 7 & 3 & 12 & 20 & $\begin{array}{l}\text { Out of } 42 \text { vendors, } \\
30 \text { give trade credit } \\
\text { and } 39 \text { receive trade } \\
\text { credit. }\end{array}$ \\
\hline
\end{tabular}

\section{REFERENCES}

Baker, G., R. Gibbons, and K. Murphy (2002) Relational Contracts and the Theory of the Firm. Quarterly Journal of Economics 117: 1, 39-84.

Banerjee, A. and K. Munshi (2000) Networks, Migration, and Investment: Insiders and Outsiders in Tirupur's Production Cluster. (Mimeographed).

Betancourt, R. and C. Clague (1981) Capital Utilisation: A Theoretical and Empirical Analysis. Cambridge: Cambridge University Press.

Deloof, M. and M. Jeger (1996) Trade Credit, Product Quality, and Intragroup Trade: Some European Evidence. Financial Management 25:3,945-68.

Fisman, R. and M. Raturi(2004) Does Competition Encourage Cooperation? Evidence from Trade Credit Relationships of African Firms. Review of Economics and Statistics 86: 1.

Government of Pakistan Board of Investment, Light Engineering, http://www.pakboi .gov.pk/pdf/Light\%20Engineering.pdf(Accessed February 6, 2010).

Greif, A. (1994) Cultural Beliefs and the Organisation of Society: A Historical and Theoretical Reflection on Collectivist and Individualist Societies. Journal of Political 
Economy 102: 5, $912-950$.

Ilias, N. (2001) Families and Firms: Labour Market Distortion in Sialkot's Surgical Industry. $\mathrm{PhD}$ Dissertation, Department of Economics, University of Pennsylvania.

Johnson, S., J. McMillan and C. Woodruff (2002) Courts and Relational Contracts. Journal of Law, Economics and Organization 18, 221-277.

Kranton, R. (1996) Reciprocal Exchange: A Self-Sustaining System. American Economic Review 86: 4, 830-51.

Macauley, S. (1963) Non-Contractual Relations in Business: A Preliminary Study. American Sociological Review 28:1, 55-69.

McMillan, J. and C. Woodruff (1999) Interfirm Relationships and Informal Credit in Vietnam. Quarterly Journal of Economics. 1285-1320.

McMillan, J. and C. Woodruff (1999) Dispute Prevention Without Courts in Vietnam. Journal of Law, Economics and Organization 15:3,637-658.

Mookherjee, D. (1999) Contractual Constraints on Firm Performance in Developing Countries. Boston University. (Mimeographed).

Nadvi, N. (1999) Collective Efficiency and Collective Failure: The Response of the Sialkot Surgical Instrument Cluster to Global Quality Pressures. World Development 27: 9, $1605-1626$.

Nadvi, K. (1999) Shifting Ties: Social Networks in the Surgical Instrument Cluster of Sialkot, Pakistan. Development and Change 30, 141-175.

North, D. (1990) Institutions, Institutional Change, and Economic Performance. Cambridge: Cambridge University Press.

Peterson, M. and R. Rajan (1997) Trade Credit: Theories and Evidence. Review of Financial Studies 10, 661-692.

Schmitz, H. and K. Nadvi (1999) Clustering and Industrialization: Introduction. World Development 27:9, 1503-1514.

Small and Medium Enterprise Development Authority (SMEDA) 2001. Surgical Instrument Industry of Pakistan: Issues in Export Growth and Development. (Government of Pakistan, (Draft Report).

Tewari, M. (1999) Successful Adjustment in Indian Industry: The Case of Ludhiana's Woolen Knitwear Cluster. World Development 27:9, 1651-1671.

Tirole, J. (1988) The Theory of Industrial Organisation. Cambridge, Massachusetts and London, England: MIT Press.

Woodruff, C. (1998) Contract Enforcement and Trade Liberalisation in Mexico's Footwear Industry. World Development 26: 6, 979-991. 
